\title{
Further Analysis of Attitude of Last Year Nursing Students in Nam Dinh University of Nursing for Blood and Body Fluids Prevention
}

\author{
Pham Thi Bich Ngoc, Hoang Thi Minh Thai, Dinh TRan Ngoc Huy
}

Abstract: This study conducted at Nam Dinh University of Nursing based on concept that Positive attitude towards occupational exposure can help nursing students self-correct their behavior in the prevention of blood and body fluid exposure. This paper aims to describe final-year nursing students' attitude of Nam Dinh University of Nursing towards preventing exposures to blood and body fluids. Related to research methods, Final year full-time nursing students were randomly selected to answer questionnaires. Research results show The mean score of the attitude towards the prevention of exposure to blood and body fluids was $3.69 \pm 0.22$ points. In which, mean scores of students' attitude towards severity; the importance of preventive measures; the role of solving, reporting, treating and monitoring post-exposure; self confidence; barriers to the practice of preventive measures are in turn $4,00 \pm 0,41$ points; $4,23 \pm 0,43$ points; 3,84 $\pm 0,48$ points; $2,8 \pm 0,47$ points; $3,61 \pm 0,43$ points. Authors conclude that attitude of final-year nursing students of Nam Dinh University of Nursing towards preventing exposures to blood and body fluids is moderate with mean score is $3,69 \pm 0,22$ points/5 points. Final-year nursing students have positive attitude towards severity and the importance of preventive measures but have negative attitude towards self confidence to do prevention measures to blood and body fluid exposures.

Key word: Attitude, Nursing Student, Exposure.

\section{INTRODUCTION}

Blood and body fluid precautions are recommendations to prevent many diseases while giving first aid or other health care that includes contact with body fluids or blood. These precautions treat all blood and body fluids as potentially infectious for diseases that are transmitted in the blood. The organisms spreading these diseases are called blood-borne pathogens.Bahadori and Sadigh (2010) said that Occupational exposure to blood and body fluids is an important hazard for health care workers, which places them at a high risk for blood-borne infections including hepatitis B

Manuscript received on 12 April 2021 | Revised Manuscript received on 31 May 2021 | Manuscript Accepted on 15 June 2021 | Manuscript published on 30 June 2021.

* Correspondence Author

Pham Thi Bich Ngoc*, Nam Dinh University of Nursing, Vietnam. Email: phamngoc.ndun@gmail.com

Hoang Thi Minh Thai, Nam Dinh Univerrsity of Nursing, Vietnam.

Dinh TRan Ngoc Huy, MBA, Banking University HCMC, Ho Chi MInh city Vietnam - International University of Japan, Japan. Email: dtnhuy2010@gmail.com

(C) The Authors. Published by Lattice Science Publication (LSP). This is an open access article under the CC-BY-NC-ND license (http://creativecommons.org/licenses/by-nc-nd/4.0/) virus, hepatitis $\mathrm{C}$ virus and human immunodeficiency virus and results in psychological and emotional stresses.

Several preventive measures have been proposed including pre-exposure (e.g., education, use of standard precautions, use of needle protective devices, and vaccination) and post-exposure (e.g., post-exposure prophylaxis and early detection of disease) prevention. In this article, the importance of occupational exposure to blood and body fluids and the basic concepts of exposure prevention and management are reviewed.

Blood and body fluid precautions apply to blood and other body fluids that contain visible traces of blood, semen, and vaginal fluids. They also apply to tissues and other body fluids, such as from around the brain or spinal cord (cerebrospinal fluid), around a joint space (synovial fluid), in the lungs (pleural fluid), in the lining of the belly and pelvis (peritoneal fluid), around the heart (pericardial fluid), and amniotic fluid that surrounds a fetus.

Exposure to blood and body fluids is one of the occupational accidents that occur in a clinical setting. This accident not only happens to medical staff, those who care for and treat patients, but can also happen to students while taking practical lessons in practice units. For nursing students, participating in hospital practice is an indispensable part of the training program with the aim of training thinking skills, clinical decision-making skills as well as developing practical capacity. nursing profession.

Exposure to blood, body fluids can occur to nursing students, mainly through skin lesions from needles or sharp objects contaminated with blood, secretions of infected persons, or blood, body fluids of infected persons. infection in contact with the damaged skin or shot into the mucosa (Alhowaish et al, 2017). The consequences of exposure to blood and body fluids increase the risk of anxiety and stress; affect physical health; affects the quality of study, reduces job opportunities, and more importantly the risk of infection with blood-borne pathogens such as HBV, HCV, HIV , ... and threatens the lives of students (Dixit et al, 2010).

Exposure is an injury or incident that involves direct skin contact with a body fluid or substance (listed below), where there is compromised skin integrity (such as an open wound, abrasion or dermatitis) or direct mucous membrane contact.

For exposure to skin, the larger the area of skin exposed and the longer the time of contact, the more important it is to verify that all the relevant skin area is intact.

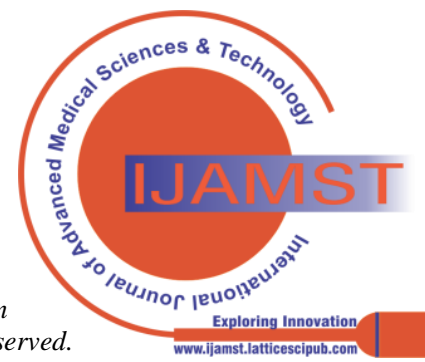


Senior nursing students and future nurses as well, will improve the quality and safety of patient care, take the lead in general hospital infection prevention and control and preventive care. occupational exposure room in particular. Therefore, this topic is done to assess the attitudes of nursing students in the last year in the prevention of exposure to blood and body fluids to have a basis for adjusting the training activities of the University. The hope that students with the right knowledge and positive attitudes can improve correct practice and safe occupational practices.

This paper organized with introduction, methodology, main results, discussion and conclusion.

\section{METHODOLOGY}

2. Subject and research method

2.1. Study design: Cross section description.

2.2. Research object: Student of the last year of Nam Dinh University of Nursing during the study period met the sampling criteria.

- Selection criteria: Final year nursing student of Nam Dinh University of Nursing and has studied infection control module in the training program and scored D or higher.

Exclusion criteria: Students were absent at the time of data collection; Students refused to participate in research.

\subsection{Time and place}

- Research period: from September 2019 to August 2020.

- Location: Nam Dinh University of Nursing

2.4. Samples and sampling methods:

- The sample size is calculated using the estimated formula for a ratio with $d=0.05 ; p=0.49$ [4]. The sample size for the study is 160 students

- Sampling method: Out of a total of 749 students of 12 full-time nursing, we randomly draw 3 classrooms out of the total of 12 classes for the Vietnam Communist Party's Revolutionary Way. . Class 12.2 results; 12.5 and 12.7 were chosen with a student population of 194 students. Based on selection and exclusion criteria we selected 182 students to participate in the study.

2.5. Tools and evaluation methods.

The tool for assessing students' attitudes about the prevention of exposure to blood, body fluids of students based on the guidelines of the Ministry of Health and the belief model of health (HBM) (Joana, 2009). The questionnaire consists of 2 parts: Part A: General information about the study object includes 7 questions; Part B. Student attitudes about prevention of exposure to blood and body fluids. Consists of 29 questions, divided into 5 areas including: Attitudes about severity of exposure; The importance of preventive measures; Attitudes about local management, reporting, treatment and follow-up roles; Self-confidence; Attitude about barriers when taking preventive measures.

A questionnaire that assesses students' attitudes about exposure to blood and body fluids includes 28 questions, designed on a 5-step Likert scale. In which, strongly agreeing 5 points, agreeing 4 points, normally agreeing 3 points, disagreeing is corresponding to 2 points and strongly disagreeing corresponding to 1 point. A positive attitude is the one that answers yes or strongly to each question. In contrast, a negative attitude is a view that disagrees or strongly disagrees. The attitudes of nursing students in the prevention of exposure were evaluated as follows:

\begin{tabular}{|l|l|}
\hline Score level & Attitude classification \\
\hline $4,0-5$ point & Positive \\
\hline $3,0-3,9$ point & Average \\
\hline $0-2,9$ point & Not positive \\
\hline
\end{tabular}

The attitude scale has been validated and calibrated by experts in the field of infection control and is highly reliable with the Cronbach's Alpha coefficient of the attitude scale of 0.747 .

2.6. Methods of data collection: self-fill based on prepared questionnaires.

2.7. Data processing and analysis. Descriptive analysis was performed on SPSS 16.0 software.

\section{MAIN RESULTS}

3.1. Characteristics of research subjects

Table 3.1. Sex distribution and vaccination status for hepatitis $B(n=182)$

a)

\begin{tabular}{|c|l|c|c|}
\hline \multicolumn{2}{|c|}{ Content } & Quantity & Ratio \% \\
\hline \multirow{2}{*}{ Sex } & Male & 19 & 10,4 \\
\cline { 2 - 4 } & Female & $\mathbf{1 6 3}$ & $\mathbf{8 9 , 6}$ \\
\hline \multirow{3}{*}{$\begin{array}{c}\text { VGB } \\
\text { vaccinated }\end{array}$} & Injected & $\mathbf{1 5 9}$ & $\mathbf{8 7 , 4}$ \\
\cline { 2 - 4 } & $\begin{array}{l}\text { Not } \\
\text { injected }\end{array}$ & 23 & 12,6 \\
\hline
\end{tabular}

Comments: Survey of 182 nursing students, course 12, in which female students account for $89 \%$ and $87.4 \%$ of students have been vaccinated with Hepatitis B vaccine.

3.2. Attitude about severity of exposure

b) Table 3.2. Attitude about severity $(n=182)$

\begin{tabular}{|c|c|c|c|}
\hline Exposure severity & $\begin{array}{c}\text { Average } \\
\pm\end{array}$ & $\begin{array}{l}\text { Lowest } \\
\text { score }\end{array}$ & $\begin{array}{l}\text { Highest } \\
\text { score }\end{array}$ \\
\hline $\begin{array}{c}\text { Risk of HIV infection after } \\
\text { exposure }\end{array}$ & $\begin{array}{c}4,07 \pm \\
0,55\end{array}$ & 3 & 5 \\
\hline $\begin{array}{c}\text { Anxiety, stress, and } \\
\text { psychological disturbance }\end{array}$ & $\begin{array}{c}3,92 \pm \\
0,61\end{array}$ & 2 & 5 \\
\hline $\begin{array}{l}\text { Time concuming and } \\
\text { finance }\end{array}$ & $\begin{array}{c}3,96 \pm \\
0,56\end{array}$ & 3 & 5 \\
\hline Impact on leaming quality & $\begin{array}{c}4,01 \pm \\
0,54\end{array}$ & 3 & 5 \\
\hline $\begin{array}{c}\text { Effect on employment } \\
\text { opportunities }\end{array}$ & $\begin{array}{c}3,97 \pm \\
0,72 \\
\end{array}$ & 2 & 5 \\
\hline Ovreall GPA & $\begin{array}{c}4,00 \pm \\
0,41\end{array}$ & 3 & 5 \\
\hline
\end{tabular}

Comments: the average point of the average attitude about the severity was $3.99 \pm 0.41$ points. In which, the attitude about the risk of being exposed to diseases transmitted through blood / secretions and the attitude related to the effect of learning quality reached over 4.0 points.

3.3. Attitude about the importance of preventive measures 
Table 3.3. Attitude on the importance of preventive measures $(\mathbf{n}=\mathbf{1 8 2})$

\begin{tabular}{|c|c|c|c|}
\hline Importance & $\begin{array}{c}\text { Average } \pm \\
\text { standard } \\
\text { deviation }\end{array}$ & $\begin{array}{c}\text { Lowest } \\
\text { score }\end{array}$ & $\begin{array}{c}\text { Highest } \\
\text { score }\end{array}$ \\
\hline $\begin{array}{c}\text { Testing for HBV, } \\
\text { VGC and HIV } \\
\text { infection is important } \\
\text { for how to prevent } \\
\text { exposure to others }\end{array}$ & $4,25 \pm 0,63$ & 2 & 5 \\
\hline $\begin{array}{c}\text { Hepatitis B vaccine is } \\
\text { an important way to } \\
\text { prevent HBV } \\
\text { exposure. }\end{array}$ & $4,45 \pm 0,54$ & 3 & 5 \\
\hline $\begin{array}{c}\text { The rehabilitation tool } \\
\text { helps you effectively } \\
\text { prevent exposure to } \\
\text { blood / body fluids. }\end{array}$ & $4,14 \pm 0,67$ & 3 & 5 \\
\hline $\begin{array}{c}\text { Adherence to practices } \\
\text { helps you reduce your } \\
\text { risk of exposure. }\end{array}$ & $4,2 \pm 0,64$ & 3 & 5 \\
\hline $\begin{array}{c}\text { Increase the use of } \\
\text { tools with birth } \\
\text { protection factors to } \\
\text { ensure safety. }\end{array}$ & $4,09 \pm 0,69$ & 2 & 5 \\
\hline Overall GPA & $\mathbf{4 , 2 3} \pm \mathbf{0 , 4 3}$ & $\mathbf{3 , 2}$ & $\mathbf{5}$ \\
\hline \multicolumn{2}{|c|}{} & & \\
\hline
\end{tabular}

Comments: the average score of the average attitude about the importance of preventive measures is $4.23 \pm 0.43$ points, the lowest score is 3.2 points and the highest score is 5 points. In which, only the attitude about aspects of the preventive measure is above 4.0 points

3.4. Attitudes about the role of post-exposure management, reporting, treatment and follow-up

Table 3.4. Attitudes about the role of post-exposure management, reporting, treatment and follow-up

\begin{tabular}{|c|c|c|c|}
\hline CONTENT & $\begin{array}{c}\text { Average } \pm \\
\text { standard } \\
\text { deviation }\end{array}$ & $\begin{array}{c}\text { Lowest } \\
\text { score }\end{array}$ & $\begin{array}{c}\text { Highest } \\
\text { score }\end{array}$ \\
\hline $\begin{array}{c}\text { Correct handling will limit } \\
\text { the risk of infection }\end{array}$ & $3,66 \pm 0,73$ & 2 & 5 \\
\hline $\begin{array}{c}\text { Reporting is an important } \\
\text { step in the exposure } \\
\text { management process }\end{array}$ & $3,6 \pm 0,71$ & 2 & 5 \\
\hline $\begin{array}{c}\text { Early preventive treatment } \\
\text { reduces the risk of infection }\end{array}$ & $3,91 \pm 0,65$ & 2 & 5 \\
\hline $\begin{array}{c}\text { Treatment adherence is the } \\
\text { single most important } \\
\text { measure in the treatment of } \\
\text { exposure prophylaxis }\end{array}$ & $4,08 \pm 0,58$ & 2 & 5 \\
\hline $\begin{array}{c}\text { Post-exposure monitoring } \\
\text { and evaluation is required }\end{array}$ & $4,17 \pm 0,62$ & 2 & 5 \\
\hline $\begin{array}{c}\text { Excessive anxiety and } \\
\text { stress increase the risk of } \\
\text { infection from exposure }\end{array}$ & $3,59 \pm 0,77$ & 1 & 5 \\
\hline Overall GPA & $\mathbf{3 , 8 4 \pm 0 , 4 8}$ & $\mathbf{2 , 5}$ & $\mathbf{5}$ \\
\hline
\end{tabular}

Comments: Overall average score of attitudes on the importance of post-exposure management, reporting, treatment and follow-up was $3.84 \pm 0.48$ points, lowest 2.5 points and highest 5 points, in which the attitude of adherence to treatment and follow-up was positive after exposure

3.5. Attitudes about confidence in preventing exposure to blood or secretions.
Table 3.5. Self-confidence attitude $(n=182)$ c)

\begin{tabular}{|c|c|c|c|}
\hline Ability (face-to-face) & $\begin{array}{c}\text { Average } \pm \\
\text { standard } \\
\text { deviation }\end{array}$ & $\begin{array}{c}\text { Lowest } \\
\text { score }\end{array}$ & $\begin{array}{c}\text { Highest } \\
\text { score }\end{array}$ \\
\hline $\begin{array}{c}\text { Believe that you will } \\
\text { not be exposed to } \\
\text { blood / body fluids } \\
\text { while performing care } \\
\text { activities for sick } \\
\text { people }\end{array}$ & $2,25 \pm 0,68$ & 1 & 4 \\
\hline $\begin{array}{c}\text { Believe that you will } \\
\text { know how to handle it } \\
\text { locally when exposed }\end{array}$ & $3,2 \pm 0,56$ & 2 & 5 \\
\hline $\begin{array}{c}\text { Believe you know how } \\
\text { to report after } \\
\text { exposure }\end{array}$ & $3,2 \pm 0,65$ & 2 & 5 \\
\hline $\begin{array}{c}\text { Believe that we adhere } \\
\text { well to preventive } \\
\text { treatment and know } \\
\text { how to follow-up and } \\
\text { evaluate after } \\
\text { exposure }\end{array}$ & $3,56 \pm 0,72$ & 2 & \\
\hline $\begin{array}{c}\text { Believe that we will } \\
\text { not be too nervous or } \\
\text { stressed when being } \\
\text { exposed }\end{array}$ & $2,36 \pm 0,79$ & 1 & 5 \\
\hline $\begin{array}{c}\text { Believe that if exposed } \\
\text { does not affect your } \\
\text { learning. }\end{array}$ & $2,8 \pm 0,47$ & 1,67 & \\
\hline Overall GPA & $\mathbf{2 , 8} \pm \mathbf{0 , 4 7}$ & $\mathbf{1 , 6 7}$ & $\mathbf{4 , 5}$ \\
\hline
\end{tabular}

Comment: The average score of self-confidence attitude is not positive with the average score of $2.8 \pm 0.47$ points, the lowest of 1.67 points and the highest of 4.5 points.self-confidence in the ability to be exposed; anxiety and stress problems; does not affect learning after exposure is at a non-positive level

3.6. Attitude about the barriers to taking preventive measures

Table 3.6. Attitude to barriers when taking preventive measures $(\mathbf{n}=\mathbf{1 8 2})$

d)

\begin{tabular}{|c|c|c|c|}
\hline $\begin{array}{c}\text { Attitude towards } \\
\text { barriers }\end{array}$ & $\begin{array}{c}\text { Average } \pm \\
\text { standard } \\
\text { deviation }\end{array}$ & $\begin{array}{c}\text { Lowest } \\
\text { score }\end{array}$ & $\begin{array}{c}\text { Highest } \\
\text { score }\end{array}$ \\
\hline $\begin{array}{c}\text { Lack of personal } \\
\text { protective } \\
\text { equipment }\end{array}$ & $3,99 \pm 0,62$ & 2 & 5 \\
\hline $\begin{array}{c}\text { Lack of tools and } \\
\text { equipment }\end{array}$ & $3,76 \pm 0,58$ & 2 & 5 \\
\hline $\begin{array}{c}\text { Lack of warning } \\
\text { system }\end{array}$ & $3,45 \pm 0,69$ & 2 & 5 \\
\hline Work overload & $3,38 \pm 0,71$ & 1 & 5 \\
\hline $\begin{array}{c}\text { Uncoordinated } \\
\text { patient }\end{array}$ & $3,59 \pm 0,69$ & 1 & 5 \\
\hline $\begin{array}{c}\text { Procedure seldom } \\
\text { performed }\end{array}$ & $3,69 \pm 0,67$ & 2 & 5 \\
\hline Overall GPA & $\mathbf{3 , 6 1} \pm \mathbf{0 , 4 3}$ & $\mathbf{2 , 5}$ & $\mathbf{5}$ \\
\hline
\end{tabular}

Published By: 
Comment: Average score of attitude about barriers when implementing preventive measures reached $3.61 \pm 0.43$ points

3.7. General attitude about prevention of exposure to blood and body fluids of students

Table 3.7. Students' general attitude about prevention of exposure to blood and body fluids

\begin{tabular}{|c|c|c|c|}
\hline $\begin{array}{c}\text { Attitude } \\
\text { about } \\
\text { prevention } \\
\text { of exposure } \\
\text { to blood }\end{array}$ & $\begin{array}{c}\text { Average } \pm \\
\text { standard } \\
\text { deviation }\end{array}$ & $\begin{array}{c}\text { Lowest } \\
\text { score }\end{array}$ & $\begin{array}{c}\text { Highest } \\
\text { score }\end{array}$ \\
\hline $\begin{array}{c}\text { General } \\
\text { attitude }\end{array}$ & $\begin{array}{c}\mathbf{3 , 6 9} \pm \\
\mathbf{0 , 2 2}\end{array}$ & 2,82 & 4,35 \\
\hline
\end{tabular}

Students' general attitude about prevention of exposure to blood and body fluids was average with an average score of $3.69 \pm 0.22$ points.

\section{DISCUSSION}

\subsection{Attitude about the Severity of Exposure}

In our study, Table 3.2 results showed that the majority of nursing students had a positive attitude about the severity of exposure to blood / body fluids with an overall mean score of $4.0 \pm 0,41$ points / 5 points. However, in each other aspect, the attitude of the students was only average, namely: anxiety, stress, and psychological disorder was only $3.99 \pm$ 0.41 points / 5 points; Time and finance only reached $3.69 \pm$ 0.42 points / 5 points; The effect on job opportunities is only $3.97 \pm 0.72$ points / 5 points. Research results of Dulcie, C. A. et al. 2017178 (89\%) students who thought themselves at risk of HIV infection in the workplace (Dulcie et al, 2017) and the study of Alhowaish, M.I. et al (2017) also reported that only $23 \%$ of students said that they are not worried about being infected with $\mathrm{HBV}$. In order to change self-care behavior to avoid the risk of exposure to blood-borne and exudate diseases, it is necessary to increase the students' positive attitudes about the severity of exposure.

\subsection{Attitude about the Importance of Preventive Measures}

According to HBM, when a person understands and believes that certain behaviors can prevent or reduce the risk of a health problem, they can act or change their behavior [8]. In this study, the results in Table 3.3 show that final-year students in the research group have a positive attitude about exposure prevention measures with an average score of 4.23 \pm 0.43 points / 5 points. . The specific contents of the preventive attitude all have a positive attitude with the overall average score of $>4.0$ points / 5 points. Our research results are similar to that of Alhowaish, M.I. et al (2017) when he said that $86.5 \%$ agree that $\mathrm{HBV}$ vaccine is safe and effective.

\subsection{Attitudes about the Role of Post-Exposure} Management, Reporting, Treatment And Follow-Up

Results of the study indicated that the senior nursing student in the study had an average attitude toward post-exposure management, reporting, treatment and follow-up with an overall GPA of 3, $84 \pm 0.48$ points / 5 points. In which, students did not have a positive attitude about measures to manage, report and control measures of anxiety and stress after exposure. The less positive attitude about the role of post-exposure management, reporting, treatment and follow-up may be due to the fact that the students in our study have never experienced clinical lesions and exposures. Therefore, there is not much experience in post-exposure management, reporting, treatment and follow-up and this is also an issue that teachers participating in training need to pay attention to to help students have correct awareness and positive attitude.

4.4. Self-confidence in preventing blood / secretions exposure.

The HBM model predicts that people who are aware that they are susceptible to a particular health problem will engage in behaviors to reduce the risk of developing the health problem. Individuals with a low level of confidence may be more likely to have health problems, when faced with real-world situations they will engage in negative behaviors and potentially increase the severity of the problem. subject. In contrast, individuals with a high level of trust are those who believe in themselves, and believe in their behaviors to avoid health problems (Joanna, 2009). Table 3.5 shows that subjects in the study have a negative attitude about their ability to cope with real situations with the average score of only $2.8 \pm 0.47$ points / 5 points. Our results are lower than those of Alhowaish, M.I. et al (2017) when he pointed out that $90 \%$ of medical students believe that following infection control guidelines will protect them from infection with HBV in the workplace (Alhowaish et al, 2017). This difference is due to the fact that the subject in our study is a senior nursing student with little clinical experience, so the level of confidence in the prevention of exposure to blood and secretions is not high.

\subsection{Attitudes about Barriers to Blood / Secretion Exposure Prevention}

Barrier perception, according to HBM, is an individual's assessment of obstacles to behavior change. Even if an individual perceives the health condition to be threatening and believes that a particular action will effectively reduce the threat, that individual will seek to overcome barriers that would prevent the problem. Health problems can occur . The results of our study in Table 3.6 show that subjects in our study have an average attitude of barriers to blood / fluid exposure prevention, with a score of only $3.61 \pm 0.43$ points / 5 points.

\subsection{General Attitude about Prevention of Exposure to Blood and Body Fluids Of Students}

The results are shown in Table 3.7. showed that the attitude of nursing students in the final year of the year on prevention of exposure to blood and body fluids was at an average level with the average score of $3.69 \pm 0.22$ points. Our results are similar to that of Huang H. et al. (2016), the average student's attitude toward exposure prevention is $31.15 \pm 6.43$ points.

\section{CONCLUSION}

The attitude of senior nursing students on the prevention of exposure to blood and body fluids was average with an average score of $3.69 \pm 0.22$ points (on a 5-point scale), of which $91.2 \%$ of students have a moderate attitude, and $8.8 \%$ of students have a positive Inside: 
Attitude about severity; the importance of exposure prevention measures was positive with an average score of $4.00 \pm 0.41$ points and $4.23 \pm 0.43$ points (5-point scale)

Self-confidence was not positive with an overall GPA of $2.8 \pm 0.47$ points (on a 5-point scale)

Although skin provides some protection from exposure to potentially infectious substances, it is strongly recommended that health professionals use blood and body fluid precautions for further protection when they are providing health care. These precautions also help protect you from exposure to a potential infection from your health professional in the unlikely event that you come in contact with the health professional's blood.

\section{ACKNOWLEDGMENT}

Authors express sincere thanks to editors, friends and $\mathrm{Mr}$ Dinh Tran Ngoc Huy (dtnhuy2010@gmail.com) to assist this publication.

\section{REFERENCES}

1. Ministry of Health (2012). Instructions for safe injection in medical examination and treatment establishments. Issued together with the Decision No. 3671 / QD-BYT of the Minister of Health on the approval of the instructions for infection control.

2. Ministry of Health (2012). Training materials for infection prevention and control, Medical Publishing House, Hanoi.

3. Ah Al-Hazmi (2015). Knowledge, attitudes, and practice of medical students regarding occupational risks of hepatitis B virus in college of medicine, aljouf university. Annals of medical and health sciences research, 5(1), pp. 13-19. [CrossRef]

4. C. A. Dulcie and et al. (2017). Assessment of knowledge about post exposure prophylaxis of HIV among medical, nursing and paramedical students in hospital and laboratory practice. International Journal Of Basic \& Clinical Pharmacology, 6(10). [CrossRef]

5. Dat, P.M., Mau, N.D., Loan, B.T.T., \& Huy, D.T.N. (2020) Comparative China Corporate Governance Standards After Financial Crisis, Corporate Scandals and Manipulation, JOURNAL OF SECURITY AND SUSTAINABILITY ISSUES, 9(3). https://doi.org/10.9770/jssi.2020.9.3(18) [CrossRef]

6. Dinh Tran Ngoc Huy. (2015). The Critical Analysis of Limited South Asian Corporate Governance Standards After Financial Crisis, International Journal for Quality Research, 9(4).

7. H. Joanna (2009). Health Belief Model. Introduction to Health Behaviour Theory, Amazon.

8. Dixit Sanjay and et al. (2010). Impact of Educational Intervention Measures on Knowledge regarding HIV/ Occupational Exposure and Post Exposure Prophylaxis among Final Year Nursing Students of a Tertiary Care Hospital in Central India. Online Journal of Health \& Allied Sciences, pp.8.

9. Le Thi Anh Thu (2010). The effectiveness of the occupational exposure prevention program at Cho Ray Hospital. Journal of Medicine in Ho Chi Minh City, 14 (2), pp. 429-435.

10. M.I. Alhowaish and et al. (2017). Knowledge, attitudes and practices toward prevention of hepatitis B virus infection among medical students at Northern Border University, Arar, Kingdom of Saudi Arabia. Electronic physician, 9(9), pp. 5388-5394. [CrossRef]

11. Melek Talas (2009). Occupational exposure to blood and body fluids among Turkish nursing students during clinical practice training: Frequency of needlestick/sharp injuries and hepatitis B immunisation. Journal of clinical nursing, 18(10), pp. 1394-403. [CrossRef]

12. Nguyen Thi Minh Chinh, Pham Thi Bich Ngoc, Nguyen Minh Loi, Dinh Thi Thu Hang, Dinh Tran Ngoc Huy, Pham Van Tung. (2021). Deepening Analysis on Preventing Fall Risk with Knowledge and Practices of Nurses and Nursing. Systematic Review in Pharmacy, 12(3): 308-313. doi:10.31838/srp.2021.3.48

13. Nguyen Lan Viet et al. (2005). Assess training needs of occupational exposure prevention for HIV at Medical Universities in Vietnam, Research paper.

14. Pham Thi Bich Ngoc, Ngo Huy Hoang, Dinh Thi Thu Hang, Dinh Tran Ngoc Huy. (2020). Evaluating Fall Prevention for Patient at Nam Dinh Hospital in Vietnam, European Journal of Molecular \& Clinical Medicine, 2020, 7(10): 3114-3119 [CrossRef]

\section{AUTHORS PROFILE}

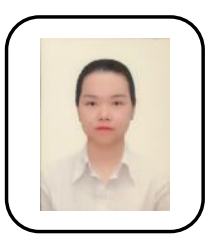

Pham Thi Bich Ngoc, is currently working at Nam Dinh University of Nursing Vietnam. She has published in many prestigous journals including scopus Q2 Systematic Review in Pharmacy, 12(3): 308-313. doi:10.31838/srp.2021.3.48 .

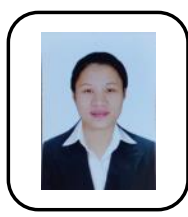

Hoang Thi Minh Thai, at present, working at Nam Dinh University of Nursing, Vietnam.. She sa published many artices in good international and local journals.

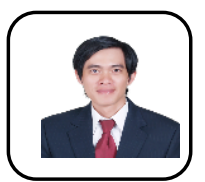

Dinh Tran Ngoc Huy, graduated from Internationa University of Japan, Niigata, Japan. He has published about 340 articles, with more than 120 ISI and Scopus articles. His website: www.dinhtranngochuy.com 